\title{
Microgram per Dose
}

National Cancer Institute

\section{Source}

National Cancer Institute. Microgram per Dose. NCI Thesaurus. Code C124462.

A unit of measure expressed in microgram(s) per dose. 